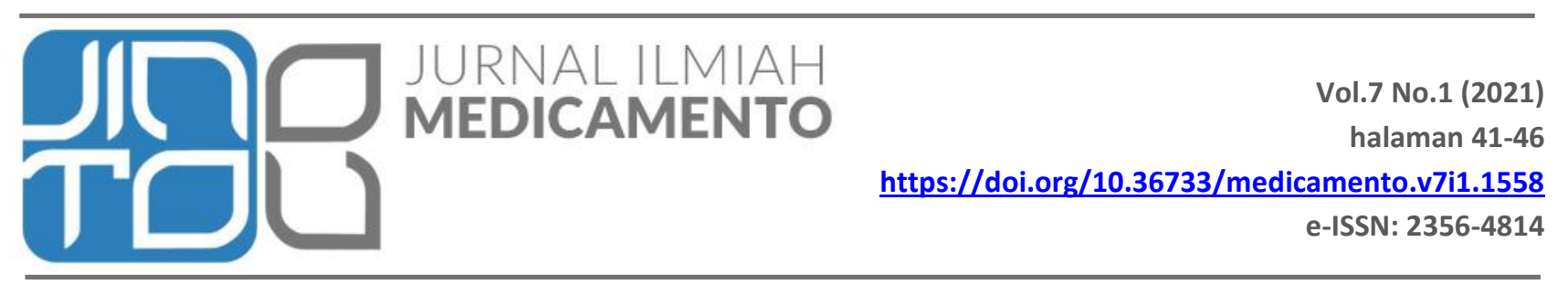

\title{
Uji Efektivitas Ekstrak Daun Pare (Momordica charantia L.) sebagai Bahan Pengawet Alami Buah Tomat
}

\section{Effectiveness Test of Pare Leaf Extract (Momordica charantia L.) As A Natural Preservative of Tomatoes}

\author{
Erna Cahyaningsih ${ }^{1 \bullet}$, Fitria Megawati ${ }^{1}$, Ni Putu Eka Artini ${ }^{1}$, \\ ${ }^{1}$ Program Studi Diploma Tiga Farmasi, Fakultas Farmasi, Universitas Mahasaraswati Denpasar, Bali, Indonesia
}

\begin{abstract}
Abstrak: Pare (Momordica charantia L.) merupakan tanaman dari suku Cucurbitaceae yang banyak terdapat di daerah tropis, berupa tumbuhan liar atau sengaja ditanam. Secara empiris masyarakat Indonesia menggunakan daun Pare untuk meningkatkan nafsu makan, sakit kuning, pencahar dan cacingan. Penelitian ini bertujuan untuk mengetahui efektivitas daun Pare sebagai bahan pengawet alami buah tomat dengan menggunakan 5 konsentrasi yaitu konsentrasi $0 \%, 2 \%, 4 \%, 6 \%$, dan $8 \%$. Pembuatan ekstrak etanol daun Pare dilakukan dengan metode maserasi sebanyak 200 gram serbuk daun Pare kemudian diekstraksi dengan pelarut etanol $96 \%$. Ekstrak yang dihasilkan diuji pendahuluan dengan skining fitokimia. Pengujian efektivitas daun Pare sebagai bahan pengawet dilakukan selama 16 hari. Selanjutnya untuk melihat pengaruh ekstrak daun Pare sebagai pengawet terhadap buah tomat maka dilakukan analisis data secara statistika dengan program SPSS 22 for windows. Hasil menunjukan ekstrak daun Pare (Momordica charantia L.) positif mengandung senyawa metabolit sekunder alkaloid, flavonoid, saponin, tanin dan steroid serta dapat digunakan sebagai bahan pengawet alami buah tomat pada konsentrasi $6 \%$ dan $8 \%$ dilihat dari analisis statistik yang telah dilakukan dengan lama waktu pengawetan selama 12 hari untuk konsentrasi $6 \%$ dan selama 16 hari untuk konsentrasi $8 \%$.
\end{abstract}

Kata Kunci: buah tomat, daun Pare (Momordica charantia L.), efektivitas antibakteri, pengawet alami, skrining fitokimia.

Abstract: Pare (Momordica charantia L.) is a plant of the Cucurbitaceae tribe which is mostly found in tropical regions, in the form of wild plants or deliberately planted. In empirical society Indonesia use the leaves Pare to increase appetite eat, sick yellow, laxatives and intestinal worms. This research aims to determine the effectiveness of the leaves Pare as a material preservative natural fruit of tomatoes by using five concentrations are concentrations of $0 \%, 2 \%, 4 \%, 6 \%$, and $8 \%$. The ethanol extract of Pare leaves was carried out by maceration method of 200 grams of Pare leaves powder and then extracted with $96 \%$ ethanol solvent. The resulting extract was tested preliminary by phytochemical screening. The effectiveness of Pare leaves as a preservative was carried out for 16 days. Next to see the effect of extracts of leaves Pare as a preservative to the fruit of tomatoes then conducted the analysis of data in statistics with SPSS 22 for windows. The results show extracts of the leaves Pare (Momordica charantia L.) positive -containing compound metabolites secondary alkaloids, flavonoids, saponins, tannins and steroids and can be used as a material preservative natural fruit of tomatoes at a concentration of $6 \%$ and $8 \%$ seen from the analysis of the statistics that have been carried out with the old preservation time for 12 days for $6 \%$ concentration and for 16 days for $8 \%$ concentration.

Keywords: Pare leaves (Momordica charantia L.), preservative naturals, screening phytochemical, the effectiveness of antibacterial, tomato fruits.

\section{PENDAHULUAN}

Bahan pangan merupakan kebutuhan pokok bagi setiap manusia. Bahan pangan sangat berhubungan erat dengan manusia yang harus dipenuhi setiap saat. Penyediaan bahan pangan harus diperhatikan dari awal sampai akhir untuk menunjang kesehatan. Namun, bahan pangan akan mengalami perubahan-perubahan yang tidak diinginkan seperti pembusukan dan ketengikan.

Perubahan-perubahan yang tidak diinginkan selama proses terjadi karena adanya reaksi kimia yang bersumber dari dalam dan luar

•email korespondensi: ernafar08@gmail.com 
bahan pangan tersebut (Purba, dkk., 2014). Pangan mudah mengalami kerusakan secara fisik, mekanis, mikrobiologis, biologis, dan kimia karena adanya karbohidrat, protein, lemak, air, vitamin, dan mineral yang terkandung di dalamnya. Atas dasar hal tersebut maka perlu dilakukan upaya pengawetan pangan untuk mempertahankan sifat fisik dan kimia pangan serta meningkatkan daya simpan agar lebih lama (Pristiadi, 2012).

Pengawet alami yang berasal dari tumbuhan memiliki keunggulan dibandingkan dengan pengawet sintetis. Pengawet alami dapat mempertahankan bahan makanan dengan biaya yang relatif murah dan ramah lingkungan (Adekalu, 2014). Bahan pengawet alami terdapat pada hampir semua tumbuh-tumbuhan dan buahbuahan yang mengandung senyawa saponin.

Senyawa saponin senyawa polifenol, yang mana senyawa ini dapat menghambat bakteri dengan cara merusak membran sitoplasma pada bakteri. Kerusakan pada membran sitoplasma dapat mencegah masuknya bahan-bahan makanan atau nutrisi yang diperlukan bakteri untuk menghasilkan energi akibatnya bakteri akan mengalami hambatan pertumbuhan dan bahkan kematian (Jaya, 2010).

Pare (Momordica charantia L.) merupakan tanaman dari suku Cucurbitaceae yang banyak terdapat di daerah tropis, berupa tumbuhan liar atau sengaja ditanam. Sering dijumpai pada halaman rumah dan kebun-kebun. Pare merupakan tanaman yang banyak di budidayakan di Indonesia, umumnya daun pare di jadikan bahan makanan untuk memasak.

Secara empiris, masyarakat Indonesia menggunakan daun Pare untuk meningkatkan nafsu makan, sakit kuning, pencahar, dan cacingan (Sari,dkk.,2016). Daun pare mengandung saponin, momordisin, momordin, karantin, resin, asam trikosanoat, asam resinat, dan vitamin A dan C (Latief, 2019). Daun pare mengandung banyak senyawa aktif dan metabolit sekunder yang baik untuk kesehatan tubuh dan mengobati berbagai penyakit.

Berdasarkan hasil uji kandungan fitokimia menunjukkan bahwa adanya kandungan flavonoid, tanin, saponin, steroid, alkaloid, dan terpenoid mampu untuk menyembuhkan luka (Wijaya, 2014). Penelitian yang dilakukan oleh Pazry (2017) menyimpulkan bahwa ekstrak etanol daun pare berpotensi sebagai alternatif obat luka kemudian, pada penelitian Putra (2017) menyimpulkan bahwa ekstrak daun pare (Momordica charantia L.) dalam konsentrasi 75\%, 50\%, dan 25\% berpengaruh sebagai antibakteri terhadap bakteri Enterococcus faecalis dan pada penelitian Undap, dkk (2017) menyimpulkan bahwa ekstrak daun pare (Momordica charantia L.) dapat menghambat pertumbuhan bakteri Staphylococcus aureus.

Selama ini daun tanaman Pare masih kurang dimanfaatkan. Berdasarkan studi literature tanaman Pare banyak digunakan sebagai antibakteri. Hal ini menunjukkan adanya potensi daun tanaman Pare berguna sebagai pengawet. Maka dalam penelitian ini dilakukan uji aktivitas daun tanaman Pare sebagai pengawet alami pada buah tomat.

\section{METODE PENELITIAN}

Alat dan Bahan Penelitian.

Alat. Baskom, blender (Miyako), alat alat gelas, rotary evaporator (Buchi), stopwatch, timbangan digital (Acis), toples kaca.

Bahan. Bahan yang digunakan pada penelitian ini adalah daun tanaman Pare yang didapat dari perumahan di daerah Kintamani, buah tomat yang berasal dari pertanian di daerah Kintamani, etanol 96\%, $\mathrm{HCl}$ Pekat, $\mathrm{HCL} 2 \mathrm{~N}, \mathrm{H}_{2} \mathrm{O}$, serbuk magnesium, larutan amil alkohol, pereaksi Dragendroff, Mayer, $\mathrm{FeCl}_{3} 5 \%$, Liebermann-Burchard.

Rancangan Penelitian. Rancangan penelitian yang digunakan adalah eksperimental dengan rancangan penelittian randomized pre-test and post-test with control group design dengan menggunakan 5 konsentrasi.

Ekstraksi. Pembuatan ekstrak etanol daun Pare dilakukan dengan metode maserasi yaitu dengan merendam serbuk daun Pare sebanyak 200 gram lalu diekstraksi dengan pelarut etanol $96 \%$ selama 
$3 \times 24$ jam, perbandingan simplisia: etanol (1:10) selanjutnya di remaserasi dengan jumlah pelarut sama sehingga total pelarut yang digunakan sebanyak $2000 \mathrm{ml}$. Kemudian ekstrak disaring, filtrat yang diperoleh dipekatkan menggunakan rotary evaporator pada suhu $50^{\circ} \mathrm{C}$ sehingga didapat ekstrak kental. Selanjutnya dibuat konsentrasi ekstrak yaitu $0 \%, 2 \%, 4 \%, 6 \%$, dan $8 \%$.

\section{Skrining Fitokimia.}

Identifikasi senyawa golongan alkaloid. Sejumlah 2 gram ekstrak dimasukkan kedalam tabung reaksi, kemudian ditetesi dengan $\mathrm{HCL} 2 \mathrm{~N}$, lalu dibagi dalam beberapa tabung reaksi. Tiap tabung ditambahkan dengan masing - masing pereaksi. Pada penambahan pereaksi mayer positif mengandung alkaloid jika membentuk endapan putih atau kuning dan pada penambahan pereaksi dragendroff positif mengandung alkaloid jika terbentuk endapan jingga (Tiwari, dkk, 2011).

\section{Identifikasi senyawa golongan flavonoid.}

Sebanyak 100 mg ekstrak ditambahkan 100 ml air kemudian didihkan dan disaring. Kedalam filtrat ditambahkan serbuk magnesium dan $1 \mathrm{ml} \mathrm{HCl}$ pekat, ditambahkan amil alkohol dikocok dengan kuat dan dibiarkan hingga memisah. Terbentuknya warna merah, kuning atau jingga dalam larutan amilalkohol menunjukkan adanya senyawa golongan flavonoid (Septiningsih dkk., 2017).

Identifikasi senyawa golongan saponin. Sebanyak 100 mg ekstrak lalu diencerkan dengan air, kemudian dikocok kuat selama 10 menit. Terbentuknya busa yang stabil dalam tabung reaksi menunjukkan adanya senyawa golongan saponin (Septiningsih, dkk., 2017).

Identifikasi senyawa golongan tanin. Uji tanin/polifenol dilakukan dengan menambahkan larutan $\mathrm{FeCl}_{3} 5 \%$ terhadap sampel. Sampel yang mengandung polifenol aka membentuk senyawa kompleks $\mathrm{Fe}^{+}{ }^{+}-$tanin/polifenol dengan ikatan koordinasi dengan terjadinya perubahan warna menjadi biru kehitaman atau hijau kecoklatan (Andriyanto, dkk, 2016).
Identifikasi senyawa golongan steroid/terpenoid. Identifikasi senyawa steroid/triterpenoid dilakukan dengan metode Liebermann-Buchard yaitu dengan penambahan asam asetat, lalu dibiarkan kemudian ditambahkan asam sulfat pekat. Uji positif terpenoid ditunjukkan dengan terjadinya warna jingga atau ungu dan uji positif steroid jika ditunjukkan dengan terbentuknya warna biru (Agustina, dkk, 2017).

\section{Pengujian aktivitas pengawet daun pare.}

Pengujian aktivitas sebagai pengawet dengan 5 konsentrasi yaitu 0\%, 2\%, 4\%, 6\% dan 8\%. Dimana masing-masing konsentarsi dibuat sebanyak 100 $\mathrm{ml}$ dengan mengencerkan ekstrak dengan etanol 96\%. Pengawetan buah tomat dilakukan dengan cara mencelupkan masing-masing 5 buah tomat ke dalam larutan ekstrak sesuai konsentrasi selama 5 detik selanjutnya dilakukan pengamatan selama beberapa hari sampai masa penyimpanan yang optimal. Pengujian dilakukan dengan mengamati perubahan tekstur dan warna sebelum dan sesudah pengawetan.

\section{Analisis data.}

Analisis data hasil penelitian dilakukan dengan mengamati ekstrak daun Pare sebagai pengawet buah tomat. Selanjutnya data yang diperoleh diuji secara statistik dengan program SPSS 22 for windows, menggunakan metode analisis varian (ANOVA) dengan tarap kepercayaan 95\% yang diikuti dengan tukey post test /post Hoc. Jika data tidak normal atau tidak memenuhi syarat uji ANOVA, maka data diuji dengan menggunakan uji Kruskal-Wallis dengan post hoc Mann-Whitney.

\section{HASIL DAN PEMBAHASAN}

Penentuan tumbuhan dilakukan di Lembaga Ilmu Pengetahuan Indonesia (LIPI), UPT Balai Konservasi Tumbuhan Kebun Raya "Eka Karya" Bedugul Bali menunjukan hasil bahwa jenis tanaman Pare adalah (Momordica charantia L.) yang berasal dari suku Cucurbitacea. 
Skrining fitokimia ekstrak merupakan uji pendahuluan senyawa apa saja yang terdapat pada suatu tanaman setelah dilakukan ekstraksi. Uji fitokimia ini berdasarkan identifikasi warna dan endapan yang terbentuk, uji fitokimia yang dilakukan yaitu meliputi alkaloid, saponin, tanin, steroid, dan flavonoid (Septiningsih dkk., 2017). Tujuan dari skrining fitokimia yaitu untuk mengetahui kandungan senyawa metabolit sekunder yang terdapat pada daun Pare sebagai pengawet alami buah tomat. Skrining fitokimia dilakukan dengan metode kualitatif dengan menambahkan suatu pereaksi masing-masing senyawa yang akan diuji dengan melihat perubahan warna dan bentuk suatu cairan yang diujikan (Kumalasari \& Andiarna, 2020). Hasil skrining fitokimia positif mengandung senyawa metabolit sekunder alkaloid, flavonoid, saponin, tanin dan steroid.

Pengujian ekstrak daun Pare sebagai pengawet alami buah tomat menggunakan 5 perlakuan yang terdiri dari 1 kontrol yang hanya menggunakan pelarut etanol $96 \%$ dan 4 konsentrasi yang menggunakan ekstrak daun Pare yang terbagi menjadi beberapa konsentrasi yaitu $2 \%, 4 \%$, 6\%, dan 8\%. Dimana masing-masing menggunakan 5 buah tomat pada setiap konsentrasi ekstrak. Pengamatan dilakukan secara organoleptis. Hasil pengujian dapat dilihat pada tabel 1.

Tabel 1. Hasil Pengamatan Daya Tahan Buah Tomat

\begin{tabular}{cc}
\hline $\begin{array}{c}\text { Konsentrasi Ekstrak } \\
\text { Daun Pare (\%) }\end{array}$ & $\begin{array}{c}\text { Daya Tahan Buah } \\
\text { Tomat (Hari) }\end{array}$ \\
\hline $\mathbf{0}$ & 5 \\
$\mathbf{2}$ & 7 \\
$\mathbf{4}$ & 9 \\
$\mathbf{6}$ & 12 \\
$\mathbf{8}$ & 16 \\
\hline
\end{tabular}

Berdasarkan tabel di atas dapat dilihat semakin besar konsentrasi ekstrak semakin lama daya simpan buah tomat. Konsentrasi $8 \%$ menunjukkan waktu penyimpanan paling lama yaitu 16 hari. Pengamatan mutu buah tomat dilakukan setelah memetik buah tomat kemudian diberikan perlakukan dengan konsentrasi $0 \%, 2 \%, 4 \%, 6 \%$, $8 \%$. Pengamatan dihentikan ketika buah tomat telah menunjukkan tanda-tanda kerusakan melalui perubahan tekstur dan warna seperti, buah tomat telah bertekstur lembek dan berwarna merah tua mendekati coklat. Hasil pengamatan dapat dilihat pada tabel 2 dan tabel 3.

Tabel 2. Pengamatan Mutu Buah Tomat

\begin{tabular}{|c|c|c|c|c|c|}
\hline \multirow{3}{*}{ Hari ke- } & \multicolumn{5}{|c|}{ Konsentrasi } \\
\hline & $0 \%$ & $2 \%$ & $4 \%$ & $6 \%$ & $8 \%$ \\
\hline & \multicolumn{5}{|c|}{$\begin{array}{c}\text { Jumlah buah tomat yang lembek, } \\
\text { keriput dan busuk }\end{array}$} \\
\hline 1 & SK & SK & SK & SK & SK \\
\hline 2 & SK & SK & SK & SK & SK \\
\hline 3 & $2 \mathrm{~K}$ & SK & SK & SK & SK \\
\hline 4 & $3 \mathrm{~L}$ & SK & SK & SK & SK \\
\hline 5 & $2 \mathrm{~B}$ & $3 K$ & SK & SK & SK \\
\hline 6 & & $2 \mathrm{~L}$ & SK & SK & SK \\
\hline 7 & & $2 \mathrm{~B}$ & $3 K$ & SK & SK \\
\hline 8 & & & $3 \mathrm{~L}$ & SK & SK \\
\hline 9 & & & $3 B$ & SK & SK \\
\hline 10 & & & & $1 \mathrm{~L}$ & SK \\
\hline 11 & & & & $2 \mathrm{~L}$ & SK \\
\hline 12 & & & & $2 B$ & SK \\
\hline 13 & & & & & SK \\
\hline 14 & & & & & $3 \mathrm{~L}$ \\
\hline 15 & & & & & $1 B$ \\
\hline 16 & & & & & $2 B$ \\
\hline
\end{tabular}

Keterangan: $\mathrm{SK}=$ Semua keras, $\mathrm{K}=$ Keriput, $\mathrm{L}=$ Lembek, $\mathrm{B}=$ Busuk

Tabel 3. Pengamatan Perubahan Warna Tomat

\begin{tabular}{|c|c|c|c|c|c|}
\hline \multirow{3}{*}{$\begin{array}{c}\text { Hari } \\
\text { ke- }\end{array}$} & \multicolumn{5}{|c|}{ Konsentrasi } \\
\hline & $0 \%$ & $2 \%$ & $4 \%$ & $6 \%$ & $8 \%$ \\
\hline & \multicolumn{5}{|c|}{ Perubahan warna buah tomat } \\
\hline 1 & MT-K & MT-K & MT-K & MT-K & MT-K \\
\hline 2 & M & MT-K & MT-K & MT-K & MT-K \\
\hline 3 & M & M & M & MT-K & MT-K \\
\hline 4 & MT & $M$ & M & M & MT-K \\
\hline 5 & MT & MT & M & M & $M$ \\
\hline 6 & & MT & M & $M$ & M \\
\hline 7 & & MT & MT & M & M \\
\hline 8 & & & MT & M & M \\
\hline 9 & & & MT & MT & M \\
\hline 10 & & & & MT & $M$ \\
\hline 11 & & & & MT & MT \\
\hline 12 & & & & MT & MT \\
\hline 13 & & & & & MT \\
\hline 14 & & & & & MT \\
\hline 15 & & & & & MT \\
\hline 16 & & & & & MT \\
\hline
\end{tabular}

Keterangan: MT-K= Merah Terang Kekuningan, $M=$ Merah, MT= Merah Tua 
Hasil pengamatan yang telah dilakukan pada tabel 2 selanjutnya di uji menggunakan uji statistik yaitu uji Kruskal-Wallis dengan post hoc Mann-Whitney sesuai hasil diketahui bahwa terdapat perbedaan bermakna/signiftikan secara statistik antara kelompok kontrol negatif dengan kelompok kontrol positif. Berdasarkan hasil uji statistik menunjukkan semakin besar konsentrasi ekstrak yang digunakan maka, semakin lama daya tahan buah tomat. Hasil tersebut menunjukkan bahwa ekstrak daun Pare dapat menghambat laju pembusukan pada buat tomat karena mengandung senyawa metabolit sekunder yang memiliki aktivitas antibakteri. Kandungan alkaloid, flavonoid, saponin, tanin dan steroid pada ekstrak daun Pare memiliki efektivitas sebagai antibakteri, senyawa ini dapat menghambat bakteri dengan cara merusak membrane sitoplasma pada bakteri (Jaya, 2010). Pengujian dihentikan ketika buah tomat telah menunjukkan tanda-tanda kerusakan yang dapat diamati dari perubahan tekstur dan warna. Kriteria yang digunakan dalam menilai kerusakan adalah adanya bercak-bercak coklat atau hitam pada kulit tomat, adanya serangan mikroorganisme dengan aroma busuk, serta buah sangat lembek karena kerusakan jarigan internal (Lospiani, dkk., 2017).

Perubahan warna buah tomat dari MT-K (Merah Terang Kekuningan), M (Merah), dan MT (Merah Tua). Buah tomat yang baru dipetik akan berwarna MT-K (Merah Terang Kekuningan), kemudian semakin lama akan berubah warna menjadi M (Merah), dan MT (Merah Tua). Berdasarkan hasil pengamatan pada tabel 3 dapat dilihat semakin besar konsentrasi ekstrak semakin lama buah tomat menunjukkan tanda-tanda kerusakan atau perubahan tekstur dan warna. Konsentrasi $8 \%$ menunjukkan perubahan tekstur dan warna paling lama dibandingkan dengan konsentrasi lainnya. Warna merah terang pada buah tomat dikarenakan buah tomat mengadung likopen.

Lycopene (likopen) sering disebut sebagai $\alpha$-karoten yaitu suatu karotenoid pigmen merah terang yang banyak ditemukan dalam buah tomat dan buah-buahan lain yang berwarna merah (Dewi, 2018). Likopen adalah pigmen yang tidak stabil dan dapat terdegradasi oleh panas, cahaya, dan oksigen melalui isomerisasi dan oksidasai (Oberoi \& Sogi, 2015). Ekstrak daun Pare mengandung salah satu senyawa metabolit sekunder yaitu flavonoid. Kandungan flavonoid digunakan sebagai antioksidan yang dapat menghambat oksidasi yang dapat menyebabkan perubahan pada likopen buah tomat (Jaya, 2010). Flavonoid terdapat dalam semua tumbuhan hijau sehingga dapat ditemukan pada setiap ekstrak tumbuhan (Arifin dan Ibrahim, 2018).

\section{SIMPULAN}

Berdasarkan hasil penelitian yang telah dilakukan dapat ditarik kesimpulan bahwa ekstrak daun Pare (Momordica charantia L.) memiliki aktivitas sebagai pengawet alami buah tomat selama 12 hari untuk konsentrasi $6 \%$ dan selama 16 hari untuk konsentrasi $8 \%$.

\section{DAFTAR PUSTAKA}

Adekalu, O. A. 2014. Post-Harvest Losses Reduction of Tomatoes (Lycopersicon esculentum L.) Stored in Natural Preservatives. Asian Journal of Agricultural and Food Sciences, Volume 02-Issue 05, October 2014.

Agustina, W., Nurhamidah., Handayani, D. 2017. Skrining Fitokimia dan Aktivitas Antioksidan Beberapa Fraksi Dari Kulit Batang Jarak (Ricinus communis L.). Jurnal Pendidikan dan IImu Kimia. 2017: 1(2): 117-122.

Andriyanto, B. E., Ardiningsih, P., Idiawati, N. 2016. Skrining Fitokimia Ekstrak Daun Belimbing Hutan (Baccaurea angulate Merr.). JKK, Tahun 2016, Volume 5(4), Halaman 9-13.

Arifin, B., Ibrahim, S. 2018. Struktur, Bioaktivitas dan Antioksidan Flavonoid. Jurnal Zarah, Vol. 6 No. 1 (2018), Halaman 21 - 29. 
Dewi, E. S. 2018. Isolasi Likopen Dari Buah Tomat (Lycopersicum Esculentum) Dengan Pelarut Heksana. Jurnal AGROTEK Vol. 5 No. 2, Agustus 2018.

Jaya, A. M. 2010. Isolasi dan uji efektivitas antibakteri senyawa saponin dari akar putri malu (Mimosa pudica). Skripsi, Jurusan Kimia Universitas Islam Negeri (UIN) Maulana Malik Ibrahim, Malang.

Kumalasari, M. L. F., \& Andiarna, F. 2020. Uji Fitokimia Ekstrak Etanol Daun Kemangi (Ocimum basilicum L). Indonesian Journal for Health Sciences. Vol. 4, No. 1, Maret 2020, Hal. $39-44$.

Latief, Abdul. 2018. Obat Tradisional. Jakarta: EGC

Lospiani, N. P.N., Utama, I. M. S., Pudja, I. A. R. P. 2017. Pengaruh Lama Waktu Cekaman Anaerobik dan Konsentrasi Emulsi Lilin Lebah Sebagai Bhan Pelapis Terhadap Mutu dan Masa Simpan Buah Tomat. Jurnal Beta (Biosistem dan Teknik Pertanian). Volume 5 (2).

Oberoi, D. P. S., Sogi, D. S. 2017. Prediction of Lycopene Degradation During Dehydration of Watermelon Pomace (cv Sugar Baby). Journal of the Saudi Society of Agricultural Sciences (2017) 16, 97 - 103.

Pazry, M. 2017. Potensi Ekstrak Etanol Daun Pare (Momordica charantia L) sebagai Alternatif Obat Penyembuh Luka Pada Punggung Mencit Jantan (Mus musculus L.). Skripsi, Jurusan Biologi Fakultas Matematika dan IImu Pengetahuan Alam Universitas Lampung, Bandar Lampung.

Pristiadi. 2012. Kajian Komparatif Aktivitas Antioksidan Formula Pengawet Alami Ekstrak Kecombrang (Nicolaia speciosa horan) dan Pola Pemisahan Kromatografis
Ekstrak Bagian-Bagian Tanaman Kecombrang. Journal of Inovation and Technology of Agroindustry, 1(1), 1-12.

Purba, R., Suseno, S. H., Izaki, A. F., \& Muttaqin, S. 2014. Aplication of Liquid Smoke and Chitosan as Natural Preservatives for Tofu and Meatballs. International Journal of Applied Science and Technology, 4(2), 212217.

Putra, Jalu Perdana. 2017. Efektivitas Daya Antibakteri Ekstrak Daun Pare (Momordica charantia L.) terhadap Pertumbuhan Bakteri Enterococcus faecalis. Naskah Publikasi, Program Studi Pendidikan Dokter Gigi Fakultas Kedokteran dan IImu Kesehatan. Yogyakarta: Universitas Muhammadiyah.

Sari, Wening., Indrawati, Lili., Dewi, C.S, AMF. 2016. Stroke Cegah dan Obati Sendiri. Jakarta: Penebar Swadaya.

Septiningsih, R., Sutanso., Indriani, D. 2017. Aktivitas Antioksidan Ekstrak Etanol Daun, Buah dan Biji Pare (Momordica charantina L.). Fitofarmaka, Vol. 7, No.1, Juni 2017.

Tiwari, P., Kumar, B., Kaur, M., Kaur, G., Kaur, H. 2011. Phytocemical Screening and Extraction: A Review. Internationale Pharmaceautica Sciencia, 1(1), 98-106.

Undap, dkk. 2017. Potensi Antibakteri Ekstrak Etanol Daun Pare (Momodica charantia) terhadap Bakteri Staphylococcus aureus. Jurnal Sains, Matematika, \& Edukasi (JSME). Vol, 5. No, 2 (Maret-April 2017).

Wijaya, B. A. 2014. Potensi Ekstrak Tangkai Daun Talas (Colocasia esculenta L.) sebagai Alternatif Obat Luka Pada Kulit Kelinci (Oryctolagus Cuniculus). Jurnal IImiah Farmasi-UNSTRAT. 3(3). 